\title{
REMEDIATION ACTIONS BY A RISK ASSESSMENT APPROACH: A CASE STUDY OF MERCURY CONTAMINATION
}

\author{
SABRINA SAPONARO*, ELENA SEZENNA and LUCA BONOMO \\ Politecnico di Milano, Dip. Ingegneria Idraulica, Ambientale, Infrastrutture Viarie, Rilevamento - \\ Sez. Ambientale, piazza Leonardo da Vinci, 32, 20133 Milano, Italy \\ (*author for correspondence, e-mail: sabrina.saponaro@polimi.it; Tel: +3902 23996432, \\ Fax: +3902 2396499)
}

(Received 18 April 2005; accepted 19 July 2005)

\begin{abstract}
The risk assessment procedure for identifying the remediation actions which may be adopted at a mercury contaminated site, when the plants are upgraded in the future, is proposed. The potentially active exposure/migration pathways in the future arrangement of the area will be due to $\mathrm{Hg}$ contaminated subsoil as a primary source (vapor inhalation and groundwater leaching) and to groundwater as a possible secondary source (transport to the point of compliance).

The data of mercury concentration in the soil were acquired through environmental monitoring campaigns, and were processed to establish the three-dimensional distribution of contamination in subsoil, to locate sources and to define their geometrical and chemical characteristics. Speciation tests of mercury in the soil indicated that the most abundant species present were poorly leachable under the site-specific environmental conditions, confirming the coefficient distribution value obtained by the leaching tests.

Analytical and numerical fate and transport modeling tools were used to locate digging zones in the contaminated subsoil, so as to reduce the possible groundwater contaminant loading and to avoid the down-gradient exceeding the concentration limit according to regulations. Remediation actions additional to civil works were required, which consists of soil digging within one contamination source, for about $22,200 \mathrm{~m}^{3}$ of soil.

In order to evaluate the Hazard Index $(H I)$ for human receptors due to $\mathrm{Hg}$ vapor inhalation, the air concentration of volatile mercury at the exposure point was estimated, based on direct measurements carried out at the site. Simulation gave $H I$ values below 1 for all tested scenarios, suggesting that public health is protected without any additional actions to the already scheduled plant upgrading and digging for groundwater protection.
\end{abstract}

Keywords: analytical modeling, human health, geostatistics, groundwater protection, mercury, numerical modeling, risk assessment, speciation, vapor concentration

\section{Notation}

$C_{\mathrm{A}} \quad \mathrm{Hg}$ vapor concentration at point of exposure $\left(\mathrm{mg} \mathrm{Hg} \mathrm{m} \mathrm{m}^{-3}\right.$ air)

$C_{\mathrm{AS}} \quad \mathrm{Hg}$ vapor concentration at the contaminated source $\left(\mathrm{mg} \mathrm{Hg} \mathrm{m}^{-3}\right.$ air)

$C_{\text {Wmax }} \quad \mathrm{Hg}$ dissolved maximum concentration at the point of compliance (mg $\mathrm{Hg} \mathrm{m}^{-3}$ water)

$C_{\text {Wmax } 1} \mathrm{Hg}$ dissolved maximum concentration at the point of compliance in the sensitivity analysis $\left(\mathrm{mg} \mathrm{Hg} \mathrm{m}^{-3}\right.$ water) 
$C_{\mathrm{T}} \quad \mathrm{Hg}$ concentration in soil source ( $\mathrm{mg} \mathrm{Hg} \mathrm{kg}^{-1}$ dry matter)

$C_{\mathrm{WS}} \quad \mathrm{Hg}$ dissolved concentration in soil source ( $\mathrm{mg} \mathrm{Hg} \mathrm{m}^{-3}$ water)

CADD Chronic Average Daily Dose $\left(\mathrm{mg} \mathrm{Hg} \mathrm{kg}^{-1}\right.$ body weight d ${ }^{-1}$ )

CV Coefficient of Variance (\%)

$\mathrm{H}$ Contaminated source height in the groundwater analytical fate and transport model $(\mathrm{m})$

HI Hazard Index (-)

$i \quad$ Hydraulic gradient (-)

$K \quad$ Hydraulic conductivity $\left(\mathrm{m} \mathrm{s}^{-1}\right)$

$K_{\mathrm{d}} \quad$ Contaminant distribution coefficient $\left(\mathrm{m}^{3}\right.$ water $\mathrm{kg}^{-1}$ dry matter)

$L \quad$ Contaminated source length in the groundwater analytical fate and transport model $(\mathrm{m})$

$n_{\mathrm{s}} \quad$ Contaminated cell number of the source in the groundwater analytical fate and transport model (-)

$\mathrm{RfD}_{\text {ing }}$ Ingestion Reference Dose ( $\mathrm{mg} \mathrm{Hg} \mathrm{kg}^{-1}$ body weight $\mathrm{d}^{-1}$ )

$\mathrm{RfD}_{\text {inh }}$ Inhalation Reference Dose $\left(\mathrm{mg} \mathrm{Hg} \mathrm{kg}^{-1}\right.$ body weight $\mathrm{d}^{-1}$ )

$W \quad$ Contaminated source width in the groundwater analytical fate and transport model $(\mathrm{m})$

$W^{\prime} \quad$ Contaminated source width in the Gaussian air dispersion model (m)

$x^{\prime} \quad$ Coordinate along $X^{\prime}$ axis in the Gaussian dispersion model of vapors in air $(\mathrm{m})$

$y^{\prime} \quad$ Coordinate along $Y^{\prime}$ axis in the Gaussian dispersion model of vapors in air (m)

$z^{\prime} \quad$ Coordinate along $Z^{\prime}$ axis in the Gaussian dispersion model of vapors in air $(\mathrm{m})$

$\delta A \quad$ Mixing zone height above the contaminated zone (m)

$\Delta C_{\mathrm{W}} \quad$ Percentage variation of the maximum dissolved mercury concentration expected at the point of compliance $(\%)$

$\theta \quad$ Soil effective porosity $\left(\mathrm{m}^{3}\right.$ air $\mathrm{m}^{-3}$ soil $)$

$\rho_{\mathrm{b}} \quad$ Soil dry bulk density ( $\mathrm{kg}$ dry matter $\mathrm{m}^{-3}$ soil)

$\rho_{\mathrm{s}} \quad$ Mineral density ( $\mathrm{kg}$ dry matter $\mathrm{m}^{-3}$ dry matter)

$\sigma_{y} \quad$ Transversal dispersivity in the Gaussian air dispersion model (m)

$\sigma_{z} \quad$ Vertical dispersivity in the Gaussian air dispersion model (m)

\section{Introduction}

Risk assessment for contaminated soils aims to evaluate whether contamination causes a risk for any receptor, and establish remediation limits so that risk from the residual contaminants is acceptable. Risk assessment procedures are based on the conceptual model (CM) of the site, that links sources to migration/exposure pathways and receptors, and estimates the possible damage to human receptors (health 
risk assessment), to environmental matrices (groundwater or superficial water), or to a specific ecosystem (ecological risk assessment) (ASTM, 1995; ASTM, 2000; ASTM, 2003; U.S. EPA, 1989; U.S. EPA, 2002a).

The characterization of the site is fundamental in defining the CM, and in assessing the risk; it should be designed to acquire both data about soil and groundwater contamination, and parameter values for fate and transport modeling of contaminants through the environmental matrices (Ferguson et al., 1998).

Different kinds of contamination events and soil heterogeneity usually cause great variability in the contaminant concentration of a site. However, characterization data processing can provide the distribution of the concentration values, from which a mean value, an upper confidence limit (UCL) on the mean, a specific percentile (i.e.: 95th or 99th) or the maximum value can be deduced; one of these values can be applied as the concentration representative of a contamination source in the risk assessment. In the health risk assessment, selecting 95\% UCL on the mean of the concentrations and the mean for the other input values will result in a calculated exposure that is close to the 95th percentile of the resulting exposure distribution; as an alternative, combining the soil mean concentration (which means in effect setting a scenario where it is equally probable that the exposed individual will be at any given location in the area) with the 95th percentile for other input values, the estimated risk is usually reasonably conservative. On the other hand, for a robust data set, $95 \%$ UCL will be quite close to the mean itself. Moreover, using the mean instead of the 95th percentile is not necessarily less conservative, because the values for the data may be such that the 95th percentile value may be higher or lower than the mean (U.S. EPA, 2004a). The spatial distribution of the sampling points can be taken into account by using geostatistical methods to deduce the 3D distribution of contaminants (Ferguson et al., 1998). Possible bias from a nonrandom sampling can be reduced by properly weighting the concentration data. Spatial weighting prevents redundancy of data by assigning a lower weight to observations that are clustered together and a higher weight to those that are spaced further apart. Methods that employ a weighting factor based on the measurable geometric distance between points include inverse distance and nearest neighbor. Kriging methods are based on statistical distance rather than geometric distance, which accounts for the non-linear model of spatial autocorrelation present in the data; moreover, kriging quantifies the error in estimates at unsampled points (Thayer et al., 2003).

Human health and environmental risk assessments for metals have proved very difficult, because environmental behavior and toxicity depend on metal chemical forms and soil properties, such as $\mathrm{pH}$ value and redox potential. Specific tests for studying metal mobility and availability should be carried out to complete data about the total concentration in soil (Evans, 1989; Holm et al., 1998; Ma and Rao, 1997). In risk assessment procedures, metal mobility in soil is taken into account by the distribution coefficient $K_{\mathrm{d}}$; this factor relates the chemical sorbed to the soil solid phase per unit mass to the concentration of chemical remaining in the soil solution at equilibrium. The number of significant influencing parameters, their variability 
in the field, and differences in experimental methods result in several orders of magnitude variability in measured metal $K_{\mathrm{d}}$ values reported in the literature (U.S. EPA, 1996), so that a site-specific measurement is recommended (Carlon et al., 2004).

Risk assessment is based on the estimation of the chemical concentration in a particular medium at the point of exposure (POE), where receptors are located, or at the point of compliance (POC). Whenever direct measurements are not available, one-, two- or three-dimensional mathematical models can be applied to simulate fate and transport mechanisms (advection, hydrodynamic dispersion, biological and chemical degradation, sorption, volatilization, etc.) through the migration pathway (ASTM, 1998). One-dimensional models do not take into account hydrodynamic dispersion of contaminants in lateral and vertical directions, resulting in underestimation of natural attenuation factors and overestimation of the chemical concentration at the POE/POC. Two-dimensional models are used in most applied procedures. Three-dimensional models provide more accurate results, but their application is still uncommon, due to calibration and validation problems (ASTM, 1998).

Models are also categorized as analytical, numerical, or a hybrid of the two (ASTM, 1998; Waterloo Hydrogeologic, 2001). Analytical models typically require simplifications at the physical model of the site (homogeneous and isotropic soil, contaminant source with regular boundaries or infinite source, etc.) and at the initial and boundary conditions (the aquifer is assumed to have an initial concentration of zero everywhere). These assumptions may greatly affect the accuracy of the simulation results, especially when some specific migration/exposure pathways are considered (i.e.: vapor inhalation from soil or groundwater (Swartjes et al., 2003)). U.S. EPA (1996) reports a comparison between Jury's infinite and finite source models and contaminant flux measured from bench scale experiments for pesticides (Lindane and Dieldrin) and monoaromatic solvents. For monoaromatic compounds the predicted fluxes were higher than the measured values, with a modeled-to-measured mean ratio of about ten, while models underestimated pesticide volatilization, with a modeled-to-measured ratio ranging between 0.42 and 0.81. In Hers et al. (2003), the Johnson-Ettinger model over-predicts the gas flow rate by a factor of three to ten, while in Kurz (2000) both underestimation and overestimation of the modeled 1,1-DCE indoor air concentration are reported, in comparison with field data. More complex numerical models may take into account soil heterogeneity, irregular contaminant sources, site-specific initial and boundary conditions, and can be used for analyses for which more detailed input is available and more detailed output is needed or desired. For both types of model, values of parameters affecting contaminant fate and transport in atmosphere and soil (i.e.: soil physical and hydrogeological characteristics, climatic and thermopluviometric data, contaminant physical properties and degradation rates) are required (ASTM, 1998; U.S. EPA, 1989).

In case of soil contamination with mercury, U.S. EPA usually sets distinct riskbased screening concentrations (Preliminary Remediation Goals - PRGs) for inorganic or organic forms. For mercury inorganic compounds in industrial soils, 
concentrations between $310 \mathrm{mg} \mathrm{Hg} \mathrm{kg}^{-1}$ (U.S. EPA, 2005a; U.S. EPA, 2004b) and $610 \mathrm{mg} \mathrm{Hg} \mathrm{kg}^{-1}$ (U.S. EPA, 2005b) are assumed to be protective of human health and the environment, whereas guideline values for organic forms (methyl-mercury) range between $62 \mathrm{mg} \mathrm{Hg} \mathrm{kg}^{-1}$ (U.S. EPA, 2004b; U.S. EPA, 2005b) and $200 \mathrm{mg}$ $\mathrm{Hg} \mathrm{kg}^{-1}$ (U.S. EPA, 2005a). These PRGs are usually modified in order to obtain site-specific cleanup goals, reflecting the contamination extension at the site and mercury chemical forms. At the East Fork Poplar Creek (TN), the earlier cleanup goal (180 $\mathrm{mg} \mathrm{Hg} \mathrm{kg}^{-1}$ ) was adjusted to $400 \mathrm{mg} \mathrm{Hg} \mathrm{kg}^{-1}$ (Schweitzel, 1997) based on speciation information. For contamination with mercury in both elemental and organic forms, soil site-specific clean up levels ranging between $23 \mathrm{mg} \mathrm{Hg} \mathrm{kg}{ }^{-1}$ (U.S. EPA, 2005c) and $35 \mathrm{mg} \mathrm{Hg} \mathrm{kg}^{-1}$ (U.S. EPA, 2002b) are reported.

This paper presents the risk assessment procedure used to locate the remediation actions which may be adopted at a mercury contaminated site, when the plants are upgraded in the future. The study focused particularly on: (i) 3D reconstruction of the contaminant distribution in order to confine sources in soil and define their geometric and chemical characteristics; (ii) speciation of mercury in soil and leachability to estimate the site-specific distribution coefficient; (iii) fate and transport analytical and numerical modeling; (iv) estimation of $\mathrm{Hg}$ vapor concentration at the POE for human receptors.

\section{Materials and Methods}

\subsection{SITE DESCRIPTION}

\subsubsection{General Information}

The site is in the hinterland of Milan (Italy), and extends over nearly $40,000 \mathrm{~m}^{2}$. The absolute elevation of the ground surface is between $116.5 \mathrm{~m}$ and $115.0 \mathrm{~m}$ above mean sea level (a.s.l.), with a gradient of about $0.2 \%$ towards the south.

It is part of a more extended chemical plant, where acetylene was produced by reacting calcium carbide with water from 1947 to 1952; production residues have been stored on the western portion of the site since the beginning of the eighties and later on were removed for disposal outside the chemical plant. From 1947 to 1977, a mercury (II) sulphate catalytic solution was also used at the chemical plant; until the beginning of the sixties, metallic mercury in the residues of the regeneration process of the exhausted catalytic solution was recovered by a torch process, located next to the northwestern portion of the site; later on, the regeneration process was performed outside the chemical plant.

At the beginning of the seventies, a thermoelectric power plant was set at the site, but it has not been in operation since 2000. In the future, the plant will be upgraded; some buildings and facilities ("bound zones") will be kept, and new buildings will be constructed. Ground surface not covered with buildings will be paved with a 
double-layer capping ( $1 \mathrm{~m}$ thick); utilities and pipelines will be positioned within the inter-layer drainage system.

Due to its past industrial activities, the site has been investigated since 2002 to assess geology, hydrogeology, and possible contamination of soil, groundwater and ambient air, with special focus on mercury. All investigation points have been georeferenced.

\subsubsection{Geology and Hydrogeology}

Local geology and hydrogeology were established by nearly ninety boreholes, with a maximum depth of between 5 and $90 \mathrm{~m}$ below ground surface (b.g.s.). Data processing resulted in the following subsurface stratigraphy: (i) sand and gravel (alloctone material), from ground surface to nearly $1.5 \mathrm{~m}$ b.g.s.; (ii) loamy sand (autoctone material), $1.5 \mathrm{~m}$ b.g.s. to $3.5 \mathrm{~m}$ b.g.s.; (iii) gravel with sand, $3.5 \mathrm{~m}$ b.g.s. to $40 \mathrm{~m}$ b.g.s. (aquifer I); (iv) clay, $40 \mathrm{~m}$ b.g.s. to $42 \mathrm{~m}$ b.g.s.; (v) gravel with loamy sand (aquifer II, not connected to the aquifer I), $42 \mathrm{~m}$ b.g.s. to nearly 90 $\mathrm{m}$ b.g.s. Underneath buildings and facilities (existing or already pulled down), the alloctone material extended $1 \mathrm{~m}$ below the foundations. Soil dry bulk density $\left(\rho_{\mathrm{b}}\right)$ was measured for 9 soil samples between $2.4 \mathrm{~m}$ and $9 \mathrm{~m}$ b.g.s.; values between 1.48 and $2.36 \mathrm{~g} \mathrm{~cm}^{-3}$ were obtained, with a mean value of $2.0 \mathrm{~g} \mathrm{~cm}^{-3}\left( \pm 0.3 \mathrm{~g} \mathrm{~cm}^{-3}\right.$ as standard deviation).

Aquifer I contained a phreatic groundwater; the piezometric surface fluctuated sinusoidally over a period of 1 year. Piezometers installed within the site were screened from $-5 \mathrm{~m}$ b.g.s. to $-20 \mathrm{~m}$ b.g.s. Figure 1 shows the piezometric surface levels drawn on the basis of two different campaigns, carried out in the months of the maximum level (September) and the minimum level (March). The groundwater flowed toward SSW, with a hydraulic gradient $i$ ranging from $0.16 \%$ (March) to $0.3 \%$ (September) and an average of $0.23 \%$. Pumping tests were used for quantifying the hydraulic conductivity $K$ of aquifer I, resulting in values from $1.2 \times$ $10^{-3}$ to $2.3 \times 10^{-3} \mathrm{~m} \mathrm{~s}^{-1}$, with a mean value of $1.8 \times 10^{-3} \mathrm{~m} \mathrm{~s}^{-1}\left( \pm 0.5 \mathrm{~m} \mathrm{~s}^{-1}\right.$ as standard deviation, $n=6$ ). The mean effective porosity $\theta$ of aquifer I was 0.26 , calculated as $\theta=1-\rho_{\mathrm{b}} / \rho_{\mathrm{s}}$ where $\rho_{\mathrm{s}}$ is the soil mineral density $\left(2.7 \mathrm{~g} \mathrm{~cm}^{-3}\right)$; this value was consistent with the literature data $(0.24-0.28)$ for gravelly-sandy sediments (Castagny, 1985). The organic carbon content of aquifer I was very low $\left(<0.05 \% \mathrm{w} \mathrm{w}^{-1}\right)$.

\subsubsection{Contamination}

Soil. 247 soil samples were collected at 91 sampling locations (within $15.5 \mathrm{~m}$ b.g.s.) and analyzed to quantify the total mercury concentration. 109 soil samples (83 samples from b.g.s. to $2 \mathrm{~m}$ b.g.s., 21 from $2 \mathrm{~m}$ to $5 \mathrm{~m}$ b.g.s., and 5 from $7 \mathrm{~m}$ to $10 \mathrm{~m}$ b.g.s.) at 62 sampling locations exceeded the concentration limit for industrial land use according to regulations ( $5 \mathrm{mg} \mathrm{kg}^{-1} \mathrm{~d}$.w.) (Repubblica Italiana, 1999). The average concentration of the whole data set was $82 \mathrm{mg} \mathrm{kg}^{-1}$ d.w. $( \pm 22 \mathrm{mg} \mathrm{kg}-1$ d.w. as mean standard deviation), with median $2.8 \mathrm{mg} \mathrm{kg}^{-1}$ d.w. and skewness 6.5 ; 
the highest concentration values were found in the superficial soil, with a maximum value of $2990 \mathrm{mg} \mathrm{kg}^{-1}$ d.w. at $0.9 \mathrm{~m}$ b.g.s.

Groundwater. Three groundwater monitoring campaigns (March 2003, September 2003, and February 2004) were carried out, resulting in concentration values always

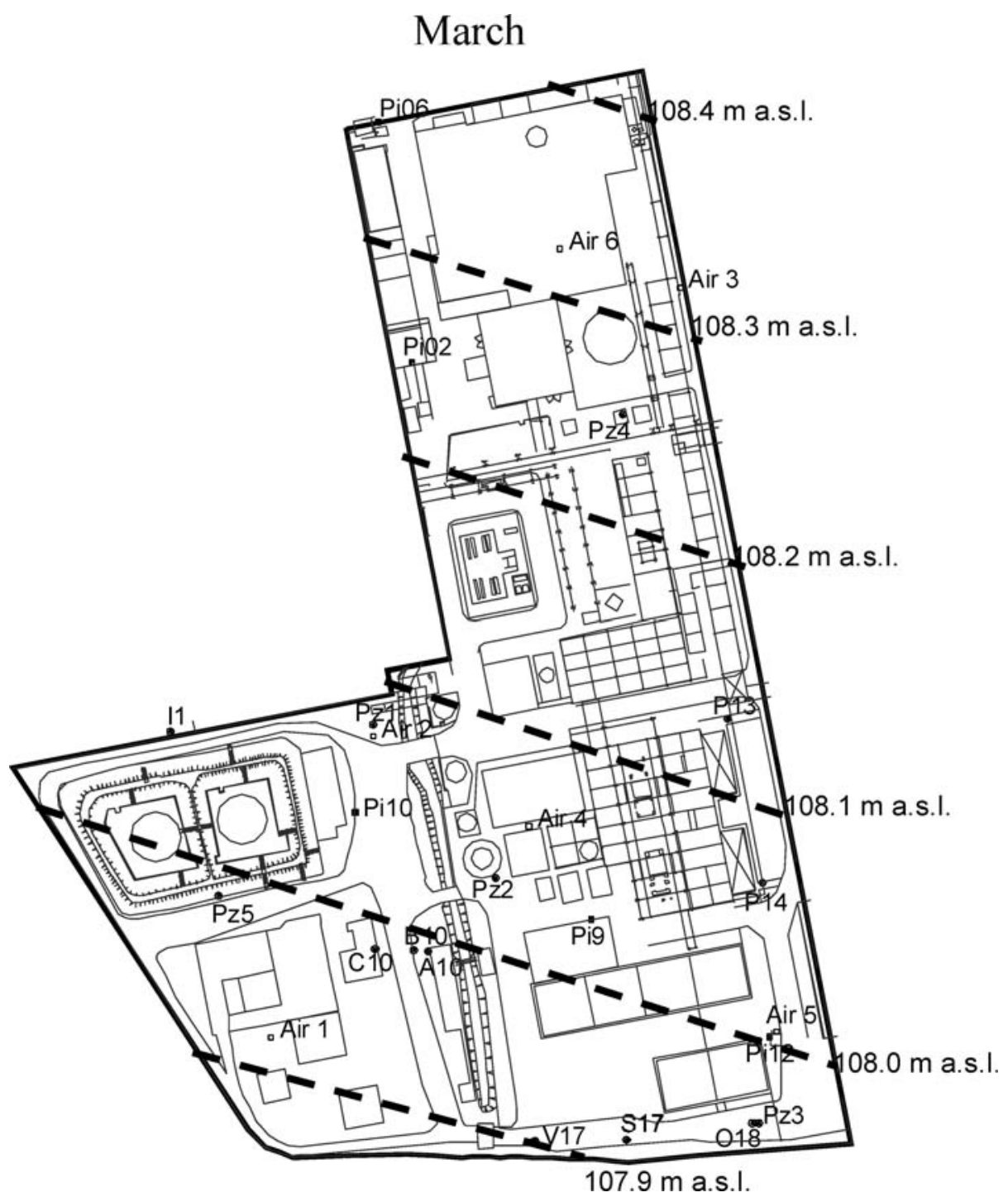

(a)

Figure 1. Phreatic levels (ENSR Italia and Politecnico di Milano, 2003) measured in groundwater monitoring campaigns: (a) March 2003, (b) September 2003. Monitoring well and air sampling locations are also shown. 


\section{September}

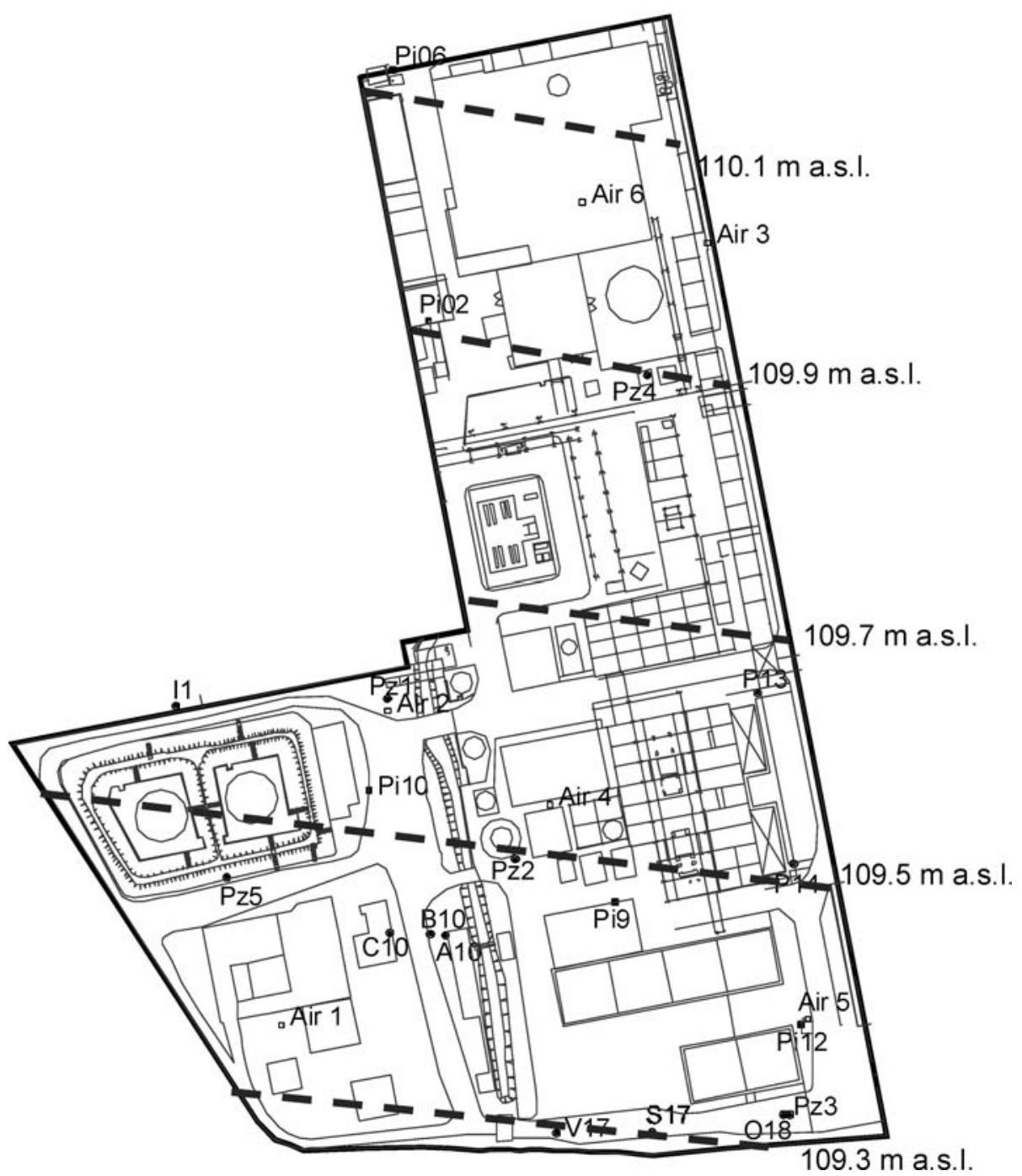

(b)

Figure 1. (Continued).

below $0.06 \mu \mathrm{g} \mathrm{l}^{-1}$, except the upgradient piezometer I1 (Figure 1) in September $2003\left(3.3 \mu \mathrm{g} \mathrm{l}^{-1}\right)$, which exceeded the regulatory limit $\left(1 \mu \mathrm{g}^{-1}\right)$ (Repubblica Italiana, 1999).

Air. An air sampling campaign was carried out during July-August 2003, in order to assess the vapor and the particulate mercury concentration both indoors ("Air 
6" in Figure 1) and outdoors ("Air 1" to "Air 5" in Figure 1). Climatic conditions during the sampling period were highly favorable to the volatilization of mercury and stagnation (mean daytime temperature above $29.7^{\circ} \mathrm{C}$ and wind velocity below $1.9 \mathrm{~m} \mathrm{~s}^{-1}$ ). Vapor concentrations were between $111 \mathrm{ng} \mathrm{m}^{-3}$ (in "Air 1") and $335 \mathrm{ng} \mathrm{m}^{-3}$ (in "Air 2"), except at the outdoor sampling location "Air 4" $\left(1030 \mathrm{ng} \mathrm{m}^{-3}\right)$, resulting in a mean value of $370 \mathrm{ng} \mathrm{m}^{-3}$. The measured particulate mercury concentrations ranged between $<1 \mathrm{ng} \mathrm{m}^{-3}$ (in "Air 4") and $9.3 \mathrm{ng} \mathrm{m}^{-3}$ (in "Air 1").

\subsection{RISK ASSESSMENT}

\subsubsection{Conceptual Model}

Mercury environmental behavior and toxicity. Mercury can exist in three oxidation states: $0\left(\mathrm{Hg}^{0}\right), 1\left(\mathrm{Hg}_{2}^{2+}\right)$, and $2\left(\mathrm{Hg}^{2+}\right)$. Most of the mercury encountered in environmental media is in the form of inorganic $\mathrm{Hg}$ (II) salts or organomercury compounds, except in the atmosphere where more than $90 \%$ is elemental mercury; $\mathrm{Hg}(\mathrm{I})$ is rarely stable under ordinary environmental conditions. The compounds most likely to be found under environmental conditions are mercuric chloride $\left(\mathrm{HgCl}_{2}\right)$, mercuric nitrate $\left(\mathrm{Hg}\left(\mathrm{NO}_{3}\right)_{2}\right)$, mercuric hydroxide $\left(\mathrm{Hg}(\mathrm{OH})_{2}\right)$, and mercuric sulphide $(\mathrm{HgS})$, as inorganic compounds, and the organic species monomethyl-mercury $\left(\mathrm{CH}_{3} \mathrm{Hg}^{+}\right)$, monomethyl-mercury chloride $\left(\mathrm{CH}_{3} \mathrm{HgCl}\right)$ and monomethyl-mercuric hydroxide $\left(\mathrm{CH}_{3} \mathrm{HgOH}\right)$; in small fractions, other organomercury compounds can be present (i.e.: dimethyl-mercury $\left(\mathrm{CH}_{3}\right)_{2} \mathrm{Hg}$, less stable than the monomethylated species, and phenyl-mercury $\mathrm{C}_{6} \mathrm{H}_{5} \mathrm{Hg}$ ) (CCME, 1996; NOAA, 1996; Twidwell, 2000; U.S. DHHS, 1999).

The $\mathrm{Hg}$ (II) species are subject to a wide array of chemical and biological reactions (INERIS, 2000; NOAA, 1996; U.S. DHHS, 1999). Soil conditions (pH, temperature and soil humic content) are typically favorable for the formation of inorganic $\mathrm{Hg}$ (II) compounds such as $\mathrm{HgCl}_{2}, \mathrm{Hg}(\mathrm{OH})_{2}$, and inorganic $\mathrm{Hg}$ (II) compounds complexed with mineral colloids or with the soil's organic matter (mainly fulvic and humic acids). $\mathrm{Hg}^{0}$ can be formed in soil by reduction of $\mathrm{Hg}$ (II) compounds/complexes mediated by humic substances and by light. Monomethylmercury and dimethyl-mercury can be formed in soil by various microbial processes acting on $\mathrm{Hg}$ (II) substances. In groundwater, additional processes can occur due to the aqueous environment. Monomethyl-mercury usually accounts for less than $10 \%$ of the total mercury; it can be produced by microbial methylation or abiotic processes (e.g. humic and fulvic acids in solution). Bacterial methylation rates appear to increase under anaerobic conditions, and moderately low $\mathrm{pH} . \mathrm{Hg}^{0}$ can be produced by humic acid reduction of $\mathrm{Hg}(\mathrm{II})$.

Elemental mercury is relatively insoluble in water. The mercuric salts vary widely in water solubility; for example the $\mathrm{HgCl}_{2}$ and $\mathrm{HgS}$ solubility products are $10^{-17.9}$ and $\approx 10^{-52}$ respectively. Most organomercury compounds are not soluble 
and do not react with weak acids or bases (U.S. DHHS, 1999). The U.S. EPA reports a solids-water distribution coefficient $\left(K_{\mathrm{d}}\right)$ for the elemental mercury of $1000 \mathrm{ml} \mathrm{g}^{-1}$ (U.S. EPA, 1997). For $\mathrm{Hg}$ (II) and monomethyl-mercury, values between 10 and $270000 \mathrm{ml} \mathrm{g}^{-1}$ are reported for soil, sediments and suspended solids (U.S. EPA, 1998a), suggesting the strong affinity of many of these compounds with the solid phase. Lyon (1997) reports values of about $6500 \mathrm{ml} \mathrm{g}^{-1}$ for inorganic mercury, and $740 \mathrm{ml} \mathrm{g}^{-1}$ for organomercury compounds in deep soil. Values for $\mathrm{Hg}$ (II) have been estimated by runs of MINTEQ2A2 simulation model, resulting in $0.04 \mathrm{ml} \mathrm{g}^{-1}$ at $\mathrm{pH}=4.9,52 \mathrm{ml} \mathrm{g}^{-1}$ at $\mathrm{pH}=6.8$, and $200 \mathrm{ml} \mathrm{g}^{-1}$ at $\mathrm{pH}=8.0$ (U.S. EPA, 1996). Battelle Memorial Institute (1989) reports values ranging from $322 \mathrm{ml} \mathrm{g}^{-1}$ to $5280 \mathrm{ml} \mathrm{g}^{-1}$, for $\mathrm{pH}$ between 5 and 9. INERIS (2000) reports $K_{\mathrm{d}}$ values between 10 and $5300 \mathrm{ml} \mathrm{g}^{-1}$ for total mercury. $\mathrm{Hg}^{0}$ is the most volatile of the mercury species; among organomercury compounds, dimethyl-mercury is more volatile than the monomethylated compounds (CCME, 1996).

The toxicity of mercury varies greatly with its chemical form and exposure pathway (CCME, 1996; INERIS, 2000; WHO, 2003). Ingested liquid elemental mercury is poorly absorbed in the digestive tract. As vapor, the main absorption route is inhalation, with the central nervous system as the main target organ. $\mathrm{Hg}^{0}$ can undergo biotransformation in the body where it is oxidized to the divalent inorganic cation, being partly retained in the kidneys and liver. Inorganic salts do not undergo appreciable biotransformation in the human body; $\mathrm{Hg}$ (II) salts absorption after ingestion is low (less than $10 \%$ of the intake), with kidneys and liver as target organs. The non carcinogenic toxicological effects for chronic exposure to monomethyl-mercury and methylated compounds are similar; the most sensitive target appears to be the central nervous system. Other organomercury compounds, such as phenyl-mercury, are toxicologically more similar to mercury inorganic salts. Absorption of organomercury compounds is faster than elemental mercury and other inorganic compounds. A certain amount of organomercury compounds can be transformed to $\mathrm{Hg}^{2+}$ in human beings, especially in the liver. Inhalation $\left(R f D_{\text {inh }}\right)$ and ingestion $\left(R f D_{\text {ing }}\right)$ reference doses reported in the literature are $8.6 \times 10^{-5}$ $\mathrm{mg} \mathrm{kg}^{-1} \mathrm{~d}^{-1}$ and $3 \times 10^{-4} \mathrm{mg} \mathrm{kg}^{-1} \mathrm{~d}^{-1}$ respectively, with reference to elemental mercury.

The IARC (International Agency for Research on Cancer) classifies methylated compounds as "possibly carcinogenic to humans" (Group 2B), on the basis of effects on experimental animals exposed to monomethyl-mercury chloride; the USEPA classifies monomethyl-mercury as a "possible human carcinogen" (Group C). Mercury inorganic salts are in the IARC Group 3 ("not classifiable as to their carcinogenicity to humans"), on the basis of inadequate evidence on humans and limited evidence on experimental animals exposed to mercuric dichloride; mercuric dichloride is classified in the USEPA Group C; no studies are available for mercuric sulphide. Elemental mercury is classified in the IARC Group 3 and in the USEPA Group D ("not classifiable as to human carcinogenicity"). No Slope Factor values are available in the literature (INERIS, 2000). 
Site specific mercury distribution in soil, chemical forms and leachability. Three dimensional ground surface shape was established by triangulation of the georeferenced sampling points using Groundwater Modeling System (GMS) v. 3.1 (Boss International, WI, and Brigham Young University, UH). A 3D mesh was created with 27778 nodes lying on 17 surfaces, each tracing the shape of the ground surface and uniformly distributed (at $1 \mathrm{~m}$ distances) along the vertical axis of a Cartesian coordinate system. In order to outline the 3D distribution of contamination in subsoil, data of mercury concentration were interpolated along the mesh nodes, using the Inverse Distance Weighted (IDW) method, with gradient plane as nodal function. However, the irregular 3D distribution of the mesh nodes did not allow practical application of results; interpolation along a regular grid is more suitable, even though usually less accurate. For this reason, the output of the interpolation along the mesh was used as input for the interpolation along cell centers of a $3 \mathrm{D}$ grid $(22 \times 33 \times 17$ cells, $10 \mathrm{~m} \times 10 \mathrm{~m} \times 1 \mathrm{~m}$ each $)$.

Mercury speciation was carried out in 15 contaminated soil samples (taken 1 to $7 \mathrm{~m}$ b.g.s), with total $\mathrm{Hg}$ concentration ranging between 5.4 and $1508 \mathrm{mg} \mathrm{kg}^{-1}$ d.w. The procedure applied allowed separation of $\mathrm{Hg}$ species into five different fractions: (i) organic $\mathrm{Hg}$; (ii) water soluble $\mathrm{Hg}$ (i.e. chloride, nitrate, sulphate); (iii) diluted acid soluble $\mathrm{Hg}$ (i.e.: oxide); (iv) concentrated acid soluble $\mathrm{Hg}$ (i.e.: metal); and (v) aqua regia soluble $\mathrm{Hg}$ (i.e. calomel, sulphide).

Soil pH-value was measured in 134 samples (taken 0.5 to $14 \mathrm{~m}$ b.g.s.); subsoil redox conditions were qualitatively assessed by means of $\mathrm{O}_{2}$ measurements $(n=$ 52 ) in the interstitial gas of the vadose zone, and by dissolved oxygen concentration measurements during the groundwater monitoring campaigns of the saturated zone.

In order to assess the site-specific $\mathrm{Hg}$ leachability and the distribution coefficient $K_{\mathrm{d}}$ in 7 soil samples (concentration between 0.4 and $2280 \mathrm{mg} \mathrm{kg}^{-1}$ d.w.), two different types of leaching tests were carried out (either deionized water or deionized water saturated with $\mathrm{CO}_{2}$ ).

Active migration/exposure pathways. Effectively or potentially active migration/exposure pathways at the site were found to be: (i) vapor inhalation and leaching from the primary source "deep soil", and (ii) transport of dissolved contamination toward the POC, due to the possible contamination of groundwater by the leachate from deep soil. Superficial soil ( $<1 \mathrm{~m}$ b.g.s.) will be removed for the civil works (capping), so that all migration/exposure pathways are removed.

Receptors. Groundwater may receive contamination released by deep soil; however, no wells within the site will pump water from aquifer I for human use.

Following plant upgrading, workers will frequent the site. Outside the area, workers are located $250 \mathrm{~m}$ toward $\mathrm{E}$, whereas resident adults and children are located $150 \mathrm{~m}$ toward N, $1000 \mathrm{~m}$ toward S, $230 \mathrm{~m}$ toward W, and beyond $1000 \mathrm{~m}$ toward E. 


\subsubsection{Groundwater Protection}

Analytical and numerical modeling tools were used to simulate mercury leaching from soil and its fate and transport in groundwater. The analytical approach was applied to each contamination source zone, in order to identify which one most affected groundwater. The numerical approach was applied to simulate the contemporary effects of all contamination sources whose plumes may overlap, and to localize the digging zones (outside the "bound zones"), so as to avoid exceeding the concentration limit according to regulations at the legal down-gradient boundary of the site ("Line Of Compliance", LOC).

Analytical modeling. Mercury fate and transport were analytically modeled with RISC 4.0 (Waterloo Hydrogeologic, 2001). In the code, the aquifer was assumed to be infinite, homogeneous, and isotropic. The source position, relative to the aquifer, changed during the year due to groundwater table fluctuations (i.e. it could be located entirely within the aquifer during part of the year, and located partially above the aquifer during the rest of the year). The source was modeled as a contaminated volume (parallelepiped), with a total soil concentration $C_{\mathrm{T}}$, constant in space over its volume. The code estimated the contaminant dissolved concentration (instantaneous process) within the source $\left(C_{\mathrm{WS}}\right)$ according to the relationship

$$
C_{\mathrm{WS}}=\frac{C_{\mathrm{T}} \cdot \rho_{\mathrm{b}}}{\rho_{\mathrm{b}} \cdot K_{\mathrm{d}}+\theta}
$$

where: (i) $\rho_{\mathrm{b}}=$ soil dry bulk density; (ii) $K_{\mathrm{d}}=$ distribution coefficient, assumed to be independent from the contaminant concentration; (iii) $\theta=$ soil effective porosity. Mass loading rate to groundwater depleted in time, due to groundwater flow through the source zone that was submerged, and to the rainwater infiltration through the source zone that was above the water table; the code accounted for mass balance, and the source "shut off" after the contaminant mass was completely depleted. The model considered three-dimensional hydrodynamic dispersion, and instantaneous and completely reversible adsorption. At the beginning of the simulation, the aquifer was assumed to have a contaminant concentration of zero; at distance from the source, the contaminant concentration was zero for all times. The simulation carried out by the code was based on the 3D analytical solution reported in Galya (1987). The monitoring well at the POC was located by the distance down-gradient from the down-gradient edge of the source, and by the possible distance from the plume centerline; at the POC, the concentration was estimated by vertically averaging the estimated concentrations over the screened interval of the well.

Hydraulic conductivity, hydraulic gradient (assumed to be toward SSW), soil dry bulk density, and effective porosity were set as the mean values measured at the site. Longitudinal, transverse and vertical dispersivities were set as the default values (10 m, $3.3 \mathrm{~m}$, and $1 \mathrm{~m}$ respectively) suggested by local and national public administrations (Province of Milan, and Agency for Environmental Protection and 
Technical Services). Since soil contamination decreases with depth from ground surface, the groundwater mean piezometric level at the site was assumed to be 112 $\mathrm{m}$ a.s.l. From an analysis of historical data of groundwater level around the site, the fluctuation around the mean level was set at $\pm 1.5 \mathrm{~m}$, and at the maximum level for $90 \mathrm{~d} \mathrm{y}^{-1}$. Rainwater infiltration rate was set at $0 \mathrm{~cm} \mathrm{y}^{-1}$, due to the superficial capping.

Mercury sources in soil and their geometrical/chemical characteristics were identified (see Results and Discussion) on the basis of soil $\mathrm{Hg}$ concentration obtained by the interpolation along the grid and exceeding the regulatory limit, also taking into account the assumed groundwater level and soil digging that will be carried out for civil works. The $K_{\mathrm{d}}$ value assumed for mercury in soil was deduced from speciation, leaching test results, and the literature (see Results and Discussion).

The simulation time was set at the maximum value that RISC can apply (100 y).

A sensitivity analysis was carried out for the source most affecting groundwater quality, and parameters whose value was assumed to be the mean value in the previous simulations $\left(K, i, \rho_{\mathrm{b}}, \theta, C_{\mathrm{T}}\right)$; variations between the minimum and the maximum values were taken into account for $K, i, \rho_{\mathrm{b}}, \theta$, and within one mean standard deviation for $C_{\mathrm{T}}$, in order to evaluate the effect on $\mathrm{Hg}$ dissolved concentration at the POC following 100 year leaching.

Numerical modeling. A simplified numerical model was applied using MT3DMS (Modular 3-Dimensional Transport Model, U.S. Army Corps of Engineers) (U.S. ACE, 1999), that uses the output flow data computed by MODFLOW (U.S. Geological Survey), and GMS v. 3.1 as input/output graphic interface. The solution approach selected was the Eulerian method, where the hydraulic head and the contaminant concentration are calculated at each integration step at the center of the cells of a fixed 3D grid. The grid was oriented toward SSW; the horizontal domain extension was $500 \mathrm{~m} \times 700 \mathrm{~m}$ around the site (cell dimensions: $5 \mathrm{~m} \times 5 \mathrm{~m}$ ); the domain was vertically divided into 10 layers, 9 of which (between $113 \mathrm{~m}$ a.s.l. and $104 \mathrm{~m}$ a.s.l.) $1 \mathrm{~m}$ high, and the deeper (between $104 \mathrm{~m}$ a.s.l. and $95 \mathrm{~m}$ a.s.l.) $9 \mathrm{~m}$ high. The aquifer was assumed to be homogeneous and isotropic, with hydraulic conductivity, soil dry bulk density, and effective porosity as in the analytical model. The flow model operated under stationary conditions, with the mean hydraulic head over the site obtained by proper hydraulic head boundary conditions. Longitudinal, transverse, and vertical dispersivities, and mercury distribution coefficient were as in the analytical model.

On the basis of analytical modeling results (see Results and Discussion), different scenarios of soil removal were simulated, precisely locating the residual contaminant sources in order to simulate their impact on groundwater quality. Contamination sources were modeled as a cluster of cells, whose dissolved contaminant concentrations $C_{\mathrm{WS}}$ were constant in time, thus neglecting soil contaminant concentration attenuation due to groundwater leaching; $C_{\mathrm{WS}}$ was related to $C_{\mathrm{T}}$ according to the Equation (1). Modeled source zones were irregular in shape, with different 
extensions within each layer, according to the interpolation results. At the beginning of the simulation, the aquifer was assumed to have a dissolved contaminant concentration of zero everywhere outside the sources.

The simulation time was as for the analytical model.

\subsubsection{Health Risk Assessment}

Health risk assessment (chronic vapor inhalation of substances with non carcinogenic toxicological effects) was carried out with RISC 4.0.

Simulated receptors. The most sensitive receptors or receptors exposed to the highest mercury concentrations in the air were selected: (i) workers at the site; (ii) resident children located $150 \mathrm{~m}$ toward $\mathrm{N}$; and (iii) resident children located $230 \mathrm{~m}$ toward W.

Exposure parameters. The exposure parameters values were selected (Table I) as the most conservative between default values reported for indoor and outdoor inhalation in GIUDITTA v. 3.0 (Provincia di Milano and URS Dames and Moore, 2003), the software adopted by the local public administration to verify risk assessment results.

Vapor concentration at the point of exposure. Mercury vapor concentration in the air inhaled by workers at the site was assumed to have the highest value measured during the monitoring campaigns.

For receptors located outside the site, no direct measurements were carried out at the POE; therefore, mercury vapor concentration $\left(C_{\mathrm{A}}\right)$ was evaluated by applying the Gaussian air dispersion model (Groundwater Services Inc., 1998). The contaminated area was geometrically modeled as a plane section, whose width $W^{\prime}$ is perpendicular to wind velocity, which is parallel to the $X^{\prime}$ axis of a Cartesian coordinate system. At a generic point with coordinates $\left(x^{\prime}, y^{\prime}, z^{\prime}\right)$, with $x^{\prime} \geq W^{\prime}$,

TABLE I

Exposure parameter values used for health risk assessment

\begin{tabular}{lcc}
\hline Exposure parameter & Worker & Children \\
\hline Body weight $(\mathrm{kg})$ & 70 & 15 \\
Lifetime $(\mathrm{y})$ & 70 & 70 \\
Inhalation rate $\left(\mathrm{m}^{3} \mathrm{~h}^{-1}\right)$ & 0.840 & 0.25 \\
Exposure time $\left(\mathrm{h} \mathrm{d}^{-1}\right)$ & 10 & 24 \\
Exposure frequency $\left(\mathrm{d} \mathrm{y}^{-1}\right)$ & 240 & 350 \\
Exposure duration $(\mathrm{y})$ & 25 & 6 \\
Lung retention factor $(-)$ & 1.0 & 1.0 \\
Absorption adjustment factor for inhalation $(-)$ & 1.0 & 1.0 \\
\hline
\end{tabular}


$C_{\mathrm{A}}$ was calculated as:

$$
\begin{aligned}
C_{\mathrm{A}}\left(x^{\prime}, y^{\prime}, z^{\prime}\right)= & C_{\mathrm{AS}} \frac{\delta A \cdot W^{\prime}}{2 \pi \cdot \sigma_{y} \cdot \sigma_{z}} \exp \left(-\frac{\left(y^{\prime}\right)^{2}}{2 \sigma_{y}^{2}}\right)\left[\exp \left(-\frac{\left(z^{\prime}-\delta A\right)^{2}}{2 \sigma_{z}^{2}}\right)\right. \\
& \left.+\exp \left(-\frac{\left(z^{\prime}+\delta A\right)^{2}}{2 \sigma_{z}^{2}}\right)\right]
\end{aligned}
$$

where: (i) $C_{\mathrm{AS}}$ is the contaminant vapor concentration in the source zone, assumed to be the mean value of data measured at the site; (ii) $\delta A$ is the ambient air mixing zone height, set at the default value $\delta A=2 \mathrm{~m}$ (Connor et al., 1996); (iii) wind direction was assumed to be constantly directed toward receptors located outside the site, and $W^{\prime}$ was assumed to be the mean extension of the site perpendicular to this direction $\left(W^{\prime}=150 \mathrm{~m}\right.$ for receptors located toward $N, W^{\prime}=230 \mathrm{~m}$ for receptors located toward $W$ ); (iv) $\sigma_{y}$ and $\sigma_{z}$ are the transverse and vertical dispersivities respectively; they depend on $x^{\prime}\left(x^{\prime}=150 \mathrm{~m}\right.$ for receptors toward $N$, and $x^{\prime}=230$ $\mathrm{m}$ for receptors toward $\mathrm{W})$, and the Pasquill-Gifford atmospheric stability class according to Briggs equations (Briggs, 1974):

$$
\begin{aligned}
\sigma_{y} & =\frac{a \cdot x^{\prime}}{\sqrt{1+b \cdot x^{\prime}}} \\
\sigma_{z} & =c \cdot x^{\prime} \cdot \sqrt{1+d \cdot x^{\prime}}
\end{aligned}
$$

For E-F Pasquill-Gifford stability classes ("stable conditions"), $a=0.11, b=$ $0.0004 \mathrm{~m}^{-1}, c=0.08$ and $d=0.00015 \mathrm{~m}^{-1}$; the estimated $\left(\sigma_{y}, \sigma_{z}\right)$ were respectively $(16.0 \mathrm{~m}, 12.1 \mathrm{~m})$ and $(24.2 \mathrm{~m}, 18.7 \mathrm{~m})$ for receptors toward $\mathrm{N}$ and $\mathrm{W}$; (v) the lateral distance from source zone $\left(y^{\prime}\right)$ and the height of breathing zone $\left(z^{\prime}\right)$ were assumed to be $y^{\prime}=0 \mathrm{~m}$ and $z^{\prime}=\delta A=2 \mathrm{~m}$.

\subsection{TEST PROCEDURES AND ANALYSES}

Soil dry bulk density was measured according to ISO 11272 core method (ISO, 1998) (Coefficient of Variance, $C V: \pm 10 \%$ ). Moisture content and $\mathrm{pH}$ values of solid samples were determined by ISO/DIS 11465 and ISO/DIS 10390 (ISO, 1994) respectively ( $C V: \pm 10 \%$, for both). Soil samples for total $\mathrm{Hg}$ analysis were treated according to EPA SW 3051 (microwave assisted acid digestion) (U.S. EPA, 1994). Total particulate matter in air was sampled and measured according to UNICHIM 271:77 gravimetric method (UNICHIM, 1989). Air particulate sampling for $\mathrm{Hg}$ analysis (low flow rate sampling) and filter treatment (acid ashing) were performed according to NIOSH 7300 method (NIOSH, 2003). Mercury vapors in air were sampled according to EPA $101 \mathrm{~A}$ (filtered impinger with $\mathrm{KMnO}_{4}$ in $\mathrm{H}_{2} \mathrm{SO}_{4}$ as absorbing solution) (U.S. EPA, 1991). Mercury concentration in soil extracts and air filter extracts, groundwater samples and absorbing solution of vapors in air was 
determined according to EPA SW 6020A (ICP-MS analysis) (U.S. EPA, 1998b), with a total $C V$ of $\pm 25 \%$ for soil and $\pm 15 \%$ in the other cases.

$\mathrm{Hg}$ speciation was performed as follows (CESI, 2003). Soil (nearly $5 \mathrm{~g}$ ) was extracted with $50 \mathrm{ml}$ deionized water/20 $\mathrm{ml}$ chloroform for $1 \mathrm{~h}$, and centrifuged at $6000 \mathrm{rpm}$ for $20 \mathrm{~min}$ at $10^{\circ} \mathrm{C}$. The liquid phases were treated with $10 \mathrm{ml} \mathrm{HCl} 0.5$ $\mathrm{N} / \mathrm{H}_{2} \mathrm{SO}_{4} 1 \mathrm{~N}$, in order to separate water soluble inorganic mercury from organomercury, which remained as chlorocomplex in the organic phase. Following separation, the organic phase was treated with $20 \mathrm{ml} \mathrm{Na}_{2} \mathrm{~S}_{2} \mathrm{O}_{3} 0.005 \mathrm{M}$, in order to transfer organomercury in the aqueous phase, which was analyzed. Nearly $1 \mathrm{~g}$ of airdried solid residue was treated with $30 \mathrm{ml} \mathrm{HNO}_{3} 0.2 \mathrm{M}$ for $1 \mathrm{~h}$ at $95{ }^{\circ} \mathrm{C}$; following separation, the liquid phase was analyzed to quantify concentrated acid soluble mercury. Solid residue was recovered and extracted at $95^{\circ} \mathrm{C}$ for $1 \mathrm{~h}$ with $30 \mathrm{ml}$ of water diluted $\mathrm{HNO}_{3}\left(1: 3 \mathrm{v} \mathrm{v}^{-1}\right)$; following separation, the liquid phase was analyzed. Solid residue was further treated with aqua regia and following separation the liquid phase was analyzed to quantify highly insoluble $\mathrm{Hg}$ species. Mercury concentration in the extracts was determined according to EPA SW 6020A (U.S. EPA, 1998b) ( $C V: \pm 15 \%)$. Organomercury extraction and backextraction yield was 93\% ( $\pm 7 \%$ as standard deviation, $n=5$ ), checked on monomethyl-mercury chloride standard solutions; the overall yield of the speciation procedure was nearly $100 \%( \pm 1.3 \%$ as mean standard deviation).

Deionized water leaching tests were performed according to UNI 10802 method (solid to liquid ratio: $1: 10 \mathrm{w} \mathrm{w}^{-1}$, contact time: $24 \mathrm{~h}$ ) (UNI, 2002); leaching tests with deionized water saturated with $\mathrm{CO}_{2}$ were performed according to regulations $\left(\mathrm{pH}<4.5\right.$, solid to liquid ratio: 1:20 $\mathrm{w} \mathrm{w}^{-1}$, contact time: $24 \mathrm{~h}$ ) (IRSA CNR, 1985; Repubblica Italiana, 1999). Mercury quantification in the extracts was carried out according to EPA 6020A (U.S. EPA, 1998b) (CV: $\pm 15 \%)$.

\section{Results and Discussion}

\subsection{SITE SPECIFIC MERCURY DISTRIBUTION IN SOIL, CHEMICAL FORMS AND LEACHABILITY}

Comparison between soil sample concentrations and estimated concentrations is shown in Figure 2; the linear regression between data resulted in a correlation coefficient $r^{2}=0.801$. 3D interpolation estimated a concentration value below the regulatory limit for nine contaminated soil samples, and a concentration value above the regulatory limit for four uncontaminated soil samples. Soil source zones outlined through 3D interpolation are shown in Figure 3 (S1 to S8); sketched areas were obtained as the union of projections of contaminated cells at different depths onto the ground surface. Bound zones are within the polygons with bold boundaries, and overlap some soil source zones (S1, S2, S4, S6 to S8).

More than $70 \% \mathrm{w} \mathrm{w}^{-1}$ of mercury in speciated soil samples was highly insoluble under natural conditions, except one soil sample where sulphide/calomel accounted 


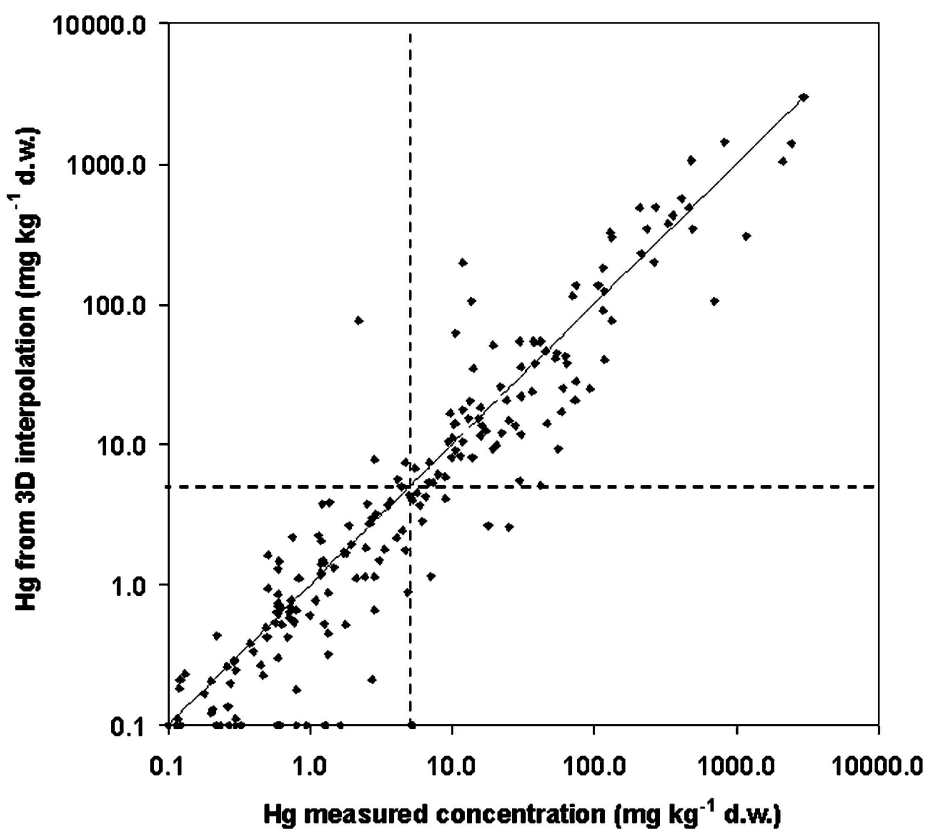

Figure 2. Comparison between soil sample analytical data and concentration values from 3D interpolation. The vertical and horizontal sketched lines crosses the abscissa and the ordinate axes respectively at the regulatory limit $\left(5 \mathrm{mg} \mathrm{kg}^{-1} \mathrm{~d}\right.$.w.).

for about $45 \% \mathrm{w} \mathrm{w}^{-1}$. Water and diluted acid soluble $\mathrm{Hg}$ species were below $3.5 \% \mathrm{w} \mathrm{w}^{-1}$, except one soil sample where $\mathrm{Hg}$ oxide accounted for $6.7 \% \mathrm{w} \mathrm{w}^{-1}$. Organomercury species were below $1.5 \mathrm{w} \mathrm{w}^{-1}$ in all samples analyzed. Elemental mercury was between $4.8 \%$ and $24 \% \mathrm{w} \mathrm{w}^{-1}$, except three soil samples with values between $33 \%$ and $38 \% \mathrm{w} \mathrm{w}^{-1}$. $\mathrm{pH}$ values and redox conditions at the site were quite homogeneous (pH: $8.4 \pm 0.1$ as mean standard deviation; oxidant environment).

The deionized water leaching test provided a distribution coefficient value (18478 $1 \mathrm{~kg}^{-1} \pm 4571 \mathrm{~kg}^{-1}$ as standard deviation) more conservative than the deionized water saturated with $\mathrm{CO}_{2}$ test $\left(333951 \mathrm{~kg}^{-1} \pm 7741 \mathrm{~kg}^{-1}\right)$. However, both values are compatible with speciation results, being within data for elemental mercury and slightly leachable $\mathrm{Hg}$ (II) species reported in the literature. In order to account for possible biotic or abiotic transformations of $\mathrm{Hg}$ (II) species in soil, $K_{\mathrm{d}}$ was assumed to have the $\mathrm{Hg}^{0}$ literature value $\left(1000 \mathrm{ml} \mathrm{g}^{-1}\right)$.

\subsection{GROUNDWATER PROTECTION}

\subsubsection{Analytical modeling}

Source zone mercury concentration, geometrical characteristics, position relative to the mean groundwater level, and distance from the POC are reported in Table II; in 


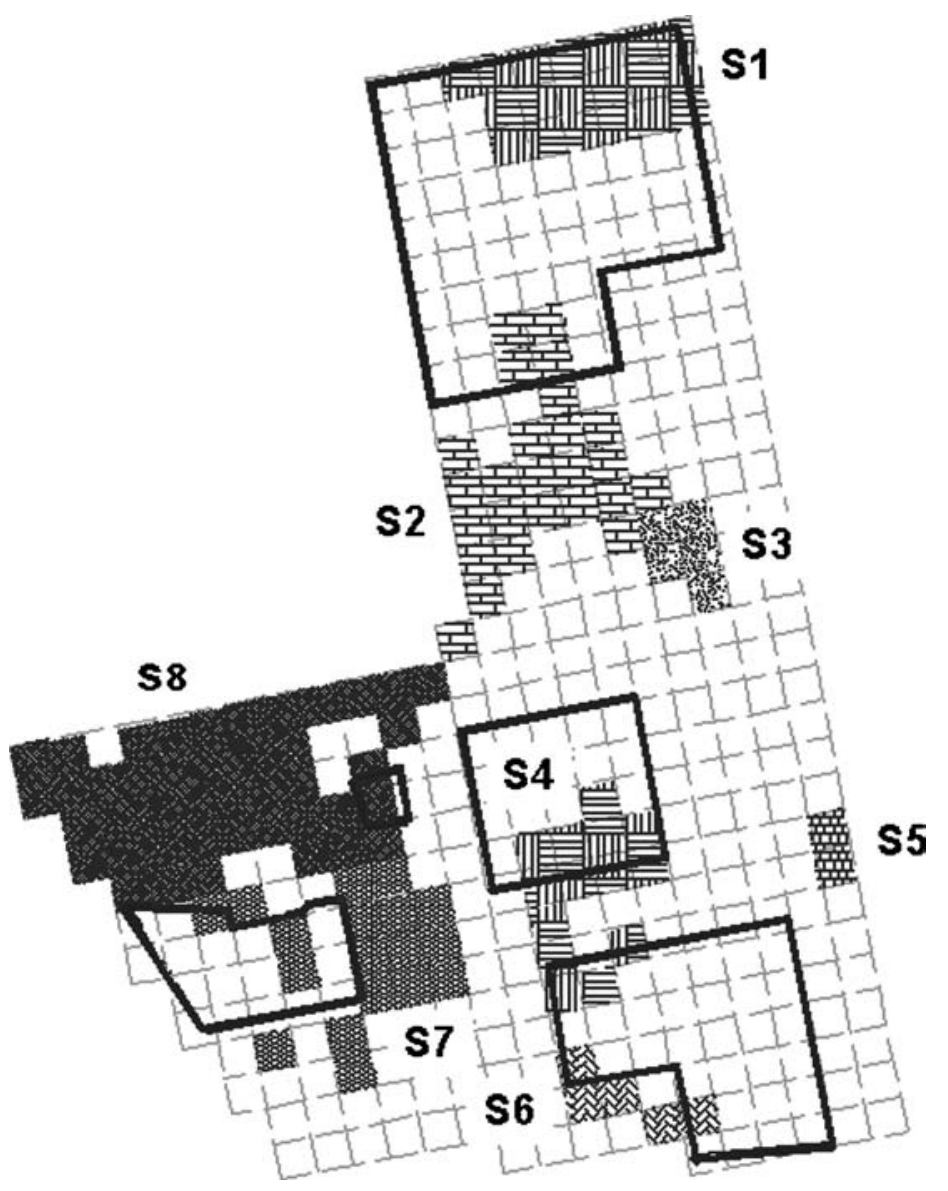

Figure 3. Source zones (S1 to S8). Bound zones are within the polygons with bold boundaries.

order to conserve the contaminant mass in each source, the width $W$ was calculated according to the relation $W=100 \mathrm{~m}^{3} n_{\mathrm{s}} \mathrm{H}^{-1} \mathrm{~L}^{-1}$, where $L$ is the source extension parallel to groundwater flow direction, $H$ is the source height, and $n_{\mathrm{s}}$ is the number of contaminated cells in the source as obtained by the grid interpolation. Some sources (S2 to S7) were confined within $4 \mathrm{~m}$ b.g.s., whereas S1 and S8 were deeper; $\mathrm{S} 7$ and $\mathrm{S} 8 \mathrm{had}$ the highest mean concentration values, due to their location in areas used for waste disposal in the past.

Maximum mercury concentration expected at the POC in the plume of each soil source $\left(C_{\mathrm{Wmax}}\right)$ is reported in Table III. S8 (partially bound zone) is the source most affecting groundwater quality, resulting by itself in a concentration value $(0.95$ $\left.\mu \mathrm{g}^{-1}\right)$ slightly lower than the regulatory limit $\left(1 \mu \mathrm{g} \mathrm{l}^{-1}\right)$; S6 and S7 (partially bound zones) contributions are about $1 / 30$ and 1/260 the regulatory limit; other source effects at the legal boundary of the site are negligible. Possible different 
TABLE II

Source zone characteristics adopted in the analytical modeling

\begin{tabular}{lllllll}
\hline & & $\begin{array}{l}C_{\mathrm{T}} \\
( \pm \text { mean s.d. } \\
\text { or s.d. } \\
\left.\text { when } n_{\mathrm{s}}<10\right)^{*} \\
\left(\mathrm{mg} \mathrm{kg}^{-1}\right)\end{array}$ & $L(\mathrm{~m})$ & $W(\mathrm{~m})$ & $\begin{array}{l}H(\mathrm{~m}) \\
\text { (from m a.s.l. } \\
\text { to m a.s.l.) }\end{array}$ & $\begin{array}{l}\text { Distance } \\
\text { from POC } \\
\text { (m) }\end{array}$ \\
Source & Type of zone & $38.7(0.8)$ & 42 & 31 & $6(108-114)$ & 275 \\
\hline S1 & Bound zone & $17.3(0.7)$ & 103 & 11 & $3(111-114)$ & 140 \\
S2 & Partially bound zone & & & & \\
S3 & Not bound zone & $5.9(0.8)$ & 28 & 11 & $2(112-114)$ & 145 \\
S4 & Partially bound zone & $18.9(0.7)$ & 67 & 11 & $3(111-114)$ & 40 \\
S5 & Not bound zone & $6.6(0.8)$ & 14 & 14 & $1(113-114)$ & 80 \\
S6 & Partially bound zone & $7.2(0.8)$ & 14 & 35 & $1(113-114)$ & 1.0 \\
S7 & Partially bound zone & $99(7)$ & 57 & 22 & $2(112-114)$ & 25 \\
S8 & Partially bound zone & $46.7(0.4)$ & 71 & 28 & $10(104-114)$ & 1.0 \\
\hline
\end{tabular}

*s.d.: standard deviation.

TABLE III

Mercury maximum concentration $C_{\mathrm{Wmax}}\left(\mu \mathrm{g} \mathrm{l^{-1 }}\right)$ predicted by the fate and transport analytical model at the POC for each source zone (S1 to S8)

\begin{tabular}{lllllllll}
\hline Source & S1 & S2 & S3 & S4 & S5 & S6 & S7 & S8 \\
\hline$C_{\text {Wmax }}$ & $<1.0 \times 10^{-17}$ & $<1.0 \times 10^{-17}$ & $<1.0 \times 10^{-17}$ & $8.5 \times 10^{-6}$ & $2.4 \times 10^{-13}$ & $3.1 \times 10^{-2}$ & $3.9 \times 10^{-3}$ & $9.5 \times 10^{-1}$ \\
\hline
\end{tabular}

TABLE IV

Percentage variation of the maximum dissolved mercury concentration expected at S8 POC; $\Delta C_{\mathrm{W}}=$ $\frac{C_{\mathrm{W}} \max 1-C_{\mathrm{W}} \max }{C_{\mathrm{W}} \max } \times 100$, with $C_{\mathrm{Wmax}}$ from Table III $\left(0.95 \mu \mathrm{g} \mathrm{l}^{-1}\right)$ and $C_{\mathrm{Wmax} 1}$ estimated with the parameter values changed

\begin{tabular}{lr}
\hline Parameter value changed & $\Delta C_{\mathrm{W}}(\%)$ \\
\hline$K=1.2 \times 10^{-3} \mathrm{~m} \mathrm{~s}^{-1}$ & -36.6 \\
$K=2.3 \times 10^{-3} \mathrm{~m} \mathrm{~s}^{-1}$ & 30.5 \\
$i=1.6 \% 0$ & -33.5 \\
$i=3.0 \% 0$ & 33.7 \\
$\rho_{\mathrm{b}}=1.48 \mathrm{~g} \mathrm{~cm}^{-3}(\theta=0.45)$ & 38.9 \\
$\rho_{\mathrm{b}}=2.36 \mathrm{~g} \mathrm{~cm}^{-3}(\theta=0.13)$ & -16.7 \\
$C_{\mathrm{T}}=47.1 \mathrm{mg} \mathrm{kg}^{-1}$ & 1.2 \\
$K=2.3 \times 10^{-3} \mathrm{~m} \mathrm{~s}^{-1}, i=3.0 \% o, \rho_{\mathrm{b}}=1.48 \mathrm{~g} \mathrm{~cm}^{-3}(\theta=0.45), C_{\mathrm{T}}=47.1 \mathrm{mg} \mathrm{kg}^{-1}$ & 47.4 \\
\hline
\end{tabular}

remediation action scenarios were formulated, which involve soil digging in the source zone S8, thus reducing mercury mass loading to groundwater.

Table IV reports sensitivity analysis results for source zone S8, as a percentage variation $\Delta C_{\mathrm{W}}$ with respect to the value reported in Table III. In the worst case simulated, the expected concentration at the POC is $1.4 \mu \mathrm{g} \mathrm{l}^{-1}$, that is nearly $47 \%$ higher than the value in Table III. 


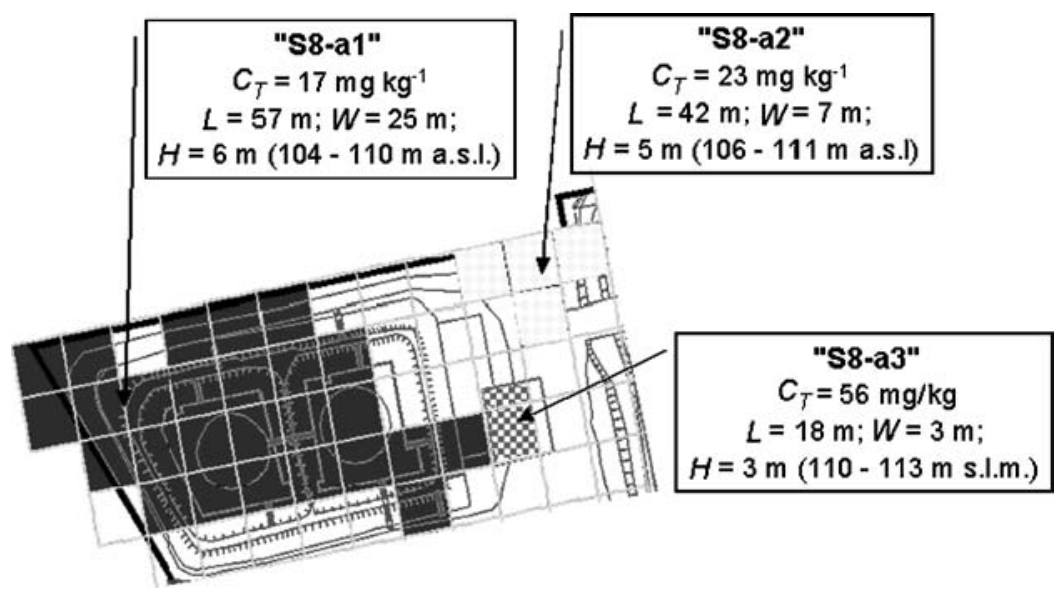

(a)

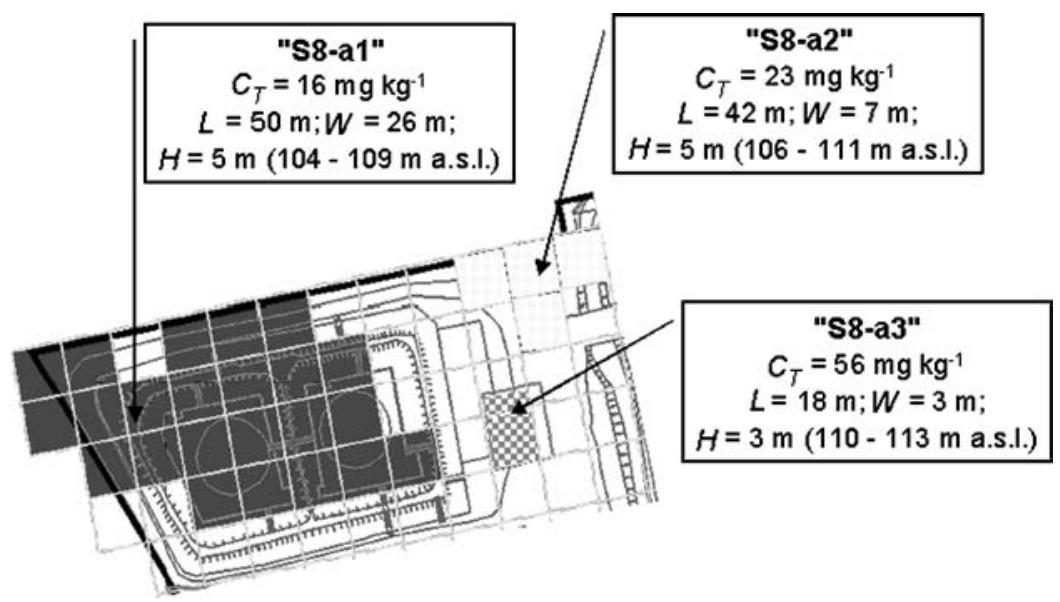

(b)

Figure 4. Source zones taken into account in two different scenarios simulated by the fate and transport numerical model (a: soil removal from ground surface to $111 \mathrm{~m}$ a.s.l. in source zone $\mathrm{S} 8$ except the sub-area S8-a3 + soil removal from ground surface to $110 \mathrm{~m}$ a.s.l. in source sub-area S8-a1; b: soil removal from ground surface to $111 \mathrm{~m}$ a.s.l. in source zone S8 except the sub-area S8-a3 + soil removal from ground surface to $109 \mathrm{~m}$ a.s.l. in source sub-area S8-a1).

\subsubsection{Numerical modeling}

Figure 4 shows residual source zones following two different remediation scenarios. In both scenarios soil will be removed from ground surface to $111 \mathrm{~m}$ a.s.l. over the entire source zone S8 except the bound sub-area S8-a3, but limitedly from the subarea S8-a1, soil digging will be extended up to $110 \mathrm{~m}$ a.s.l. in scenario (a), and up to $109 \mathrm{~m}$ a.s.l in scenario (b). Figure 4 also shows the concentration given to cells in each source zone (mean value of cell concentration values from 3D interpolation), which differs from the value adopted in the analytical modeling for the source S8, 
due to the partial soil removal. Figure 5(a) and (b) show numerical simulation results for scenarios (a) and (b) respectively. In both cases, plume extension at the end of the simulation time was drawn with a bold solid line, corresponding to the regulatory limit iso-concentration curve $\left(1 \mu \mathrm{g} \mathrm{l}^{-1}\right)$, which resulted within the down-gradient legal boundary of the site (bold hatched line) limitedly to scenario (b).

\subsection{HEALTH RISK ASSESSMENT}

Mercury vapor concentrations $C_{\mathrm{A}}$ at the outside POE were $177 \mathrm{ng} \mathrm{m}^{-3}$ for human receptors located toward $\mathrm{N}$ and $118 \mathrm{ng} \mathrm{m}^{-3}$ for human receptors located toward

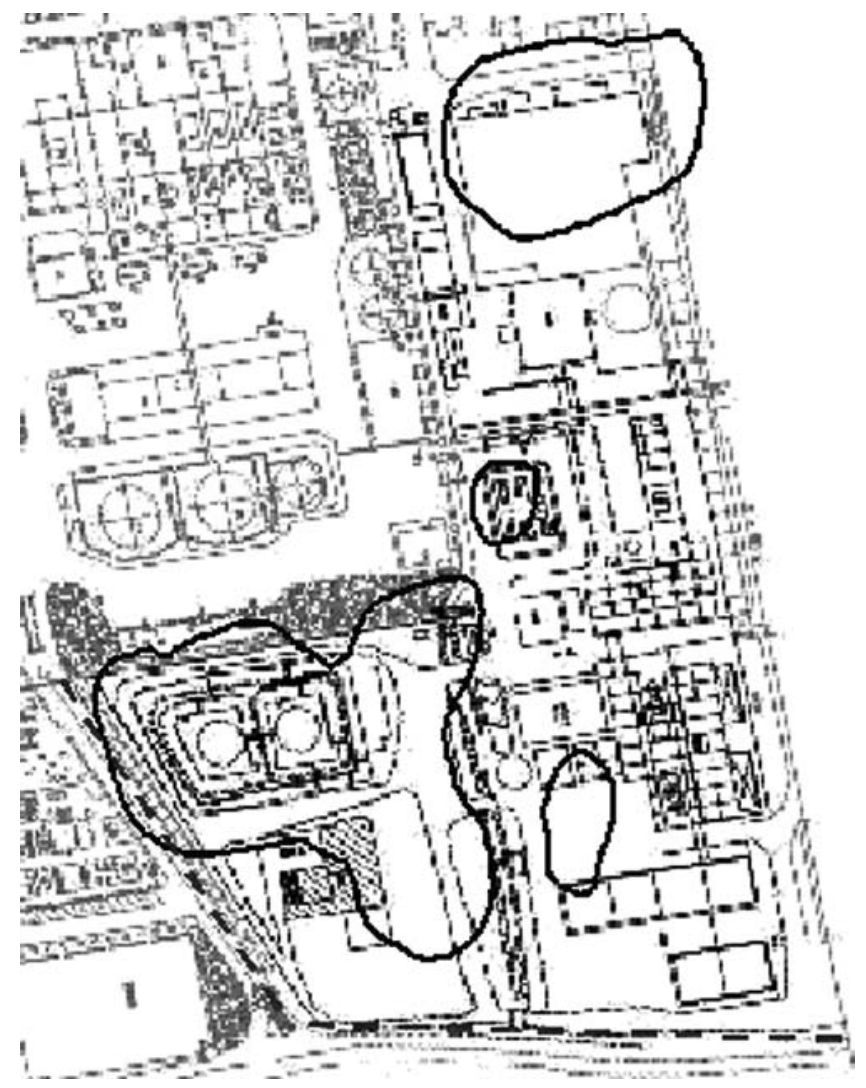

(a)

Figure 5. Numerical simulation results: (a) soil removal from ground surface to $111 \mathrm{~m}$ a.s.1. in S8 source zone (except for the sub-area S8-a3) + soil removal from ground surface to $110 \mathrm{~m}$ a.s.l. in S8-a1 source sub-area; (b): soil removal from ground surface to $111 \mathrm{~m}$ a.s.l. in S8 source zone (except for the sub-area S8-a3) + soil removal from ground surface to $109 \mathrm{~m}$ a.s.l. in S8-a1 source sub-area. Plume extension is drawn with a bold solid line, and the down-gradient legal boundary of the site with a bold hatched line. 


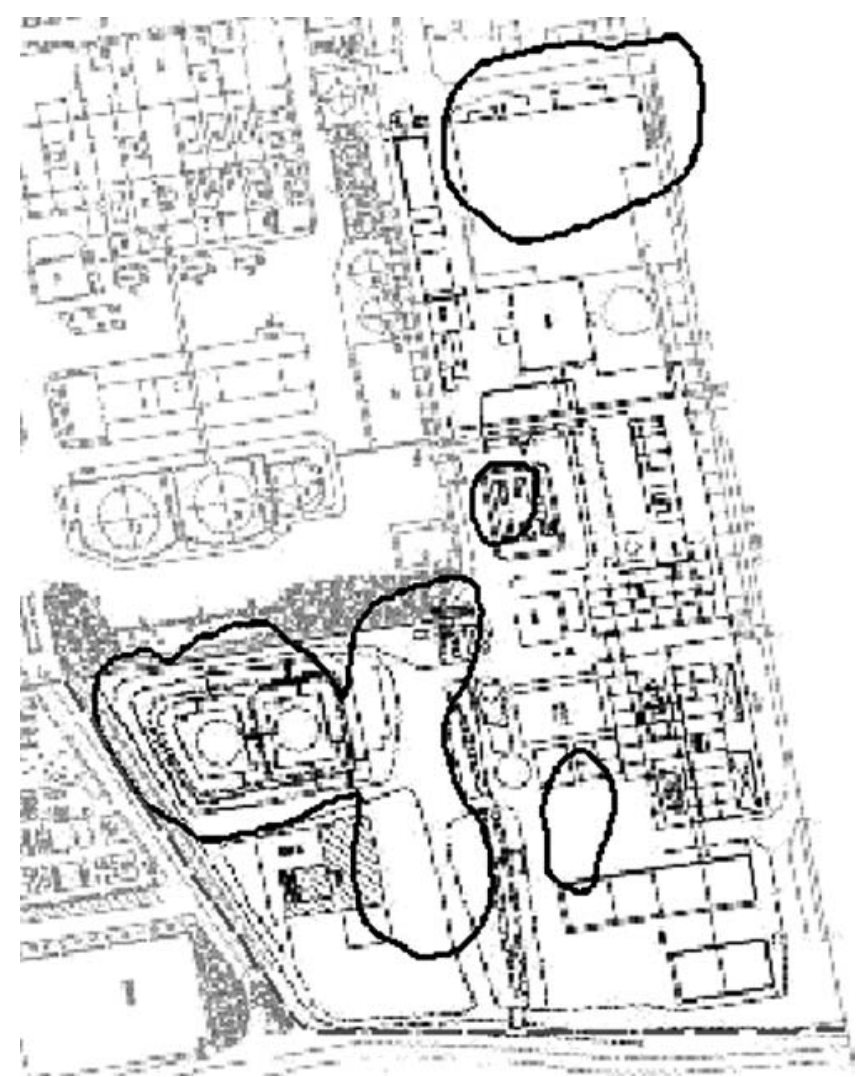

(b)

Figure 5. (Continued)

W; these values are conservative with respect to values which may be measured following the remediation action at the site, as they do not take into account soil removal and superficial capping which reduce vapor emissions.

Chronic Average Daily Doses CADD obtained for workers at the site, children resident toward $\mathrm{N}$, and children resident toward $\mathrm{W}$ were $8.1310^{-5} \mathrm{mg} \mathrm{kg}^{-1} \mathrm{~d}^{-1}$, $6.7910^{-5} \mathrm{mg} \mathrm{kg}^{-1} \mathrm{~d}^{-1}$, and $4.5310^{-5} \mathrm{mg} \mathrm{kg}^{-1} \mathrm{~d}^{-1}$ respectively, resulting in Hazard Index values $\left(\mathrm{HI}=\mathrm{CADD} / \mathrm{RfD}_{\text {inh }}\right)$ of $0.94,0.79$ and 0.53 respectively. For contaminants with non carcinogenic toxicological effects for chronic exposure such as mercury, dangers for human health are related to an $\mathrm{HI}$ value above 1; therefore, an acceptable human health risk was found for all receptors of concern, both at the site and outside the area, without action other than soil removal for civil works and groundwater protection. Vapor emission analytical modeling tools, such as equation reported in ASTM (1998), could also be applied to estimate indoor or outdoor air concentrations of mercury; however, the estimation obtained by applying the default values accepted by the local authorities for the parameters included in the model 
results in concentration values respectively 0.50 and 6.4 times the maximum values measured at the site ("Air 6" as indoor location, and "Air 4" as outdoor location). The HI related to these concentration values differs in the same factors, suggesting a possible underestimation of risk for the indoor exposure or the necessity of further remediation action in order to prevent public health damage from outdoor exposure.

\section{Conclusions}

Plant upgrading and site reuse require remediation actions which break links among contamination sources, migration/exposure pathways, and receptors, as described in the Conceptual Model of the site. Potentially active migration/exposure pathways at the site following civil works are due to mercury contamination in deep soil as a primary source (vapor inhalation and groundwater leaching), and to groundwater as a possible secondary source (transport of dissolved contamination toward the POC). Mercury soil concentrations were processed in order to establish the 3D distribution of contamination in subsoil, to locate contamination sources and to define their geometrical and chemical characteristics. Speciation tests of mercury in soil indicated that the most abundant species present are poorly leachable under the site-specific environmental conditions, confirming the coefficient distribution value obtained by leaching tests. Taking into account possible biotic or abiotic transformations of mercury species in soil, a $K_{\mathrm{d}}$ value was selected and used in the fate and transport modeling tools.

Analytical and numerical models were used to locate the remediation actions (additional to civil works) necessary to prevent groundwater contamination outside the site, which consists of soil digging: (i) $18,000 \mathrm{~m}^{3}$, from ground surface to $111 \mathrm{~m}$ a.s.l. (about $-4.5 \mathrm{~m}$ b.g.s.) over contamination source $\mathrm{S} 8$ except the sub-area S8-a3 $\left(4000 \mathrm{~m}^{2}\right.$ ), and (ii) $4,200 \mathrm{~m}^{3}$, from $111 \mathrm{~m}$ a.s.l. to $109 \mathrm{~m}$ a.s.l. (about $-6.5 \mathrm{~m}$ b.g.s.) over the sub-area S8-a1 $\left(2100 \mathrm{~m}^{2}\right)$, for a total of about $22,200 \mathrm{~m}^{3}$ of soil.

In order to evaluate the Hazard Index for human receptors from $\mathrm{Hg}$ vapor inhalation, the air concentration of volatile mercury at the exposure point was estimated, based on direct measurements carried out at the site. Simulation gave HI values below 1 for all tested receptors, suggesting that public health is protected without any additional actions to the already scheduled civil works and digging for groundwater protection.

Dig soil will be treated on site by a soil washing plant, in order to separate particles with different sizes and to isolate contaminated fines (particles smaller than a cut-off size) from not contaminated large particles (sand and gravel), that can be returned to the site, as suggested by results of preliminary laboratory tests. The extraction of mercury from soil does not seem a suitable option, due to the poor leachability of the chemical forms present in this specific soil; therefore, contaminated fines will be landfilled. Costs related to these actions were estimated 
to be the same as about $40 \%$ of costs necessary to remediate the site at $5 \mathrm{mg} \mathrm{kg}^{-1}$ d.w. as the soil concentration limit, which are affordable costs within the economic plan of the plant upgrading project.

\section{Acknowledgments}

This research was financed by Air Liquide Italia. The authors thank Marziale Messa (Air Liquide Italia) and ENSR Italia for their cooperation.

\section{References}

ASTM: 1995, 'Emergency standard guide for Risk Based Corrective Action applied at petroleum release sites', E-1739-95, Reapproved 2002, American Society for Testing and Materials, West Conshohocken.

ASTM: 1998, 'RBCA fate and transport models: Compendium and selection guidance', American Society for Testing and Materials, West Conshohocken.

ASTM: 2000, 'Standard Guide to Risk-Based Corrective Action', E2081-00, American Society for Testing and Materials, West Conshohocken.

ASTM: 2003, 'Standard Guide to Risk-based Corrective Action for Protection of Ecological Resources, E2502-02', American Society for Testing and Materials, West Conshohocken.

Battelle Memorial Institute: 1989, 'Chemical Data Bases for the Multimedia Environmental Pollutant Assessment System (MEPAS): Version 1', Prepared for the U.S. Department of Energy under Contract DE-AC06-76RKI 1830, by Pacific Northwest Laboratory operated by Battelle Memorial Institute, Geneve.

Briggs, G. A.: 1974, 'Diffusion Estimation for Small Emissions', Report ATDL-106, U.S. Atomic Energy Commission, Oak Ridge.

Carlon, C., Dalla Valle, M. and Marcomini, A.: 2004, 'Regression models to predict water-soil heavy metals partition coefficients in risk assessment studies', Environ. Pollut. 127, 109-115.

Castagny, G.: 1985, Idrogeologia: Principi e Metodi, Flaccovio Editore, Palermo, 243 pp.

CCME: 1996, 'Canadian Soil Quality Guidelines for Contaminated Sites - Human Health Effects: Inorganic Mercury', Canadian Council of Ministers of Environment.

CESI: 2003, 'Speciazione del Mercurio in Campioni di Terreno', Rapporto tecnico A3/038713, Centro Elettrotecnico Sperimentale Italiano, AMB Ambiente, 6 pp.

Connor, J. A., Newell, C. J. and Malander, M. W.: 1996, 'Parameter Estimation Guidelines for Risk-Based Corrective Action (RBCA) Modeling', in National Ground Water Association (ed.), Proceedings of the Petroleum Hydrocarbons and Organic Chemicals in Groundwater Conference, Houston, TX, USA, 13-15 November 1996.

ENSR Italia and Politecnico di Milano: 2003, 'Energheia S.r.1. - Centrale di Cogenerazione - Limito di Pioltello (MI) - Relazione della Caratterizzazione e Modello Concettuale, Milano.

Evans, L. J.: 1989, 'Chemistry of metal retention by soils', Environ. Sci. Technol. 23, 1046-1056.

Ferguson, C., Darmendrail, D., Freier, K., Jensen, B. K., Jensen, J., Kasamas, H., Urzelai, A. and Vegter, J.: 1998, Risk Assessment for Contaminated Sites in Europe, LQM Press, Nottingham, $165 \mathrm{pp}$.

Galya, D. P.: 1987, 'A horizontal plane source model for ground-water transport', Ground Water 25, 733-739.

Groundwater Services Inc.: 1998, 'Manual of RBCA Tool Kit for Chemical Releases', Houston. 
Hers, I., Zapf-Gilje, R., Johnson, P. and Li, L.: 2003, 'Evaluation of the Johnson and Ettinger Model for Prediction of Indoor Air Quality', Groundwater Monitoring and Remediation 23, 6276.

Holm, P. E., Christensen, T. H., Lorenz, S. E., Hamon, R. E., Domingues, H. C., Sequeira, E. M. and McGrath, S. P.: 1998, 'Measured soil water concentrations of cadmium and zinc and plant plots and estimated leaching outflows from contaminated soils', Water, Air, and Soil Pollut. 102, $105-115$.

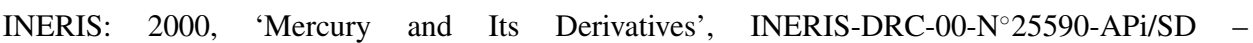
$\mathrm{N}^{\circ}$ 99DF389a.doc, Version n. 1, Institut National de 1'Environnement Industriel et des Risques, Verneuil-en-Halatte.

IRSA CNR: 1985, 'Metodi Analitici per Fanghi', Quaderno 64, Istituto di Ricerca Sulle Acque Consiglio Nazionale delle Ricerche, Roma.

ISO: 1994, 'Soil Quality - General Aspects; Chemical, and Physical Methods of Analysis; Biological Methods of Analysis', ISO/TC 190/SC 3, International Organization for Standardization, Geneve.

ISO: 1998, 'Soil Quality - Determination of Dry Bulk Density', International Organization for Standardization, Geneve.

Kurz, D. W.: 2000, 'Estimating Residential Indoor Air Impacts Due to Groundwater Contamination', Proceedings of the 2000 Conference on Hazardous Waste Research - Environmental Challenges and Solutions to Resource Development, Production, and Use, Denver, CO, USA, 23-25 May 2000, pp. 220-226.

Lyon, B.: 1997, 'Calculation of soil - water and benthic sediment partition coefficients for mercury', Chemosphere 35, 791-808.

Ma, L. Q. and Rao, G. N.: 1997, 'Chemical fractionation of cadmium, copper, nickel and zinc in contaminated soils', J. Environ. Qual. 26, 259-264.

NIOSH: 2003, 'Manual of Analytical Methods - Elements by ICP', National Institute for Occupational Safety and Health, Washington DC.

NOAA: 1996, 'Contaminants in Aquatic Habitats at Hazardous Waste Sites: Mercury', Technical Memorandum NOS ORCA 100, National Oceanic and Atmospheric Administration, Seattle.

Provincia di Milano and URS Dames \& Moore: 2003, 'GIUDITTA - Gestione Informatizzata di Tollerabilità Ambientale, v. 3.0 - Manuale d'uso', Milano.

Repubblica Italiana: 1999, 'Regolamento Recante Criteri, Procedure e Modalità per la Messa in Sicurezza, la Bonifica e il Ripristino Ambientale dei Siti Inquinati, ai sensi dell'Articolo 17 del Decreto Legislativo 5 febbraio 1997, n. 22, e Successive Modificazioni e Integrazioni', Decreto Ministeriale 25 ottobre 1999 n. 471, Roma.

Schweitzer, M.: 1997, 'Decision Making Related to the Clean-up of Mercury Contamination at Lower East Fork Popular Creek: Workshop Summary Report', Technical Report NCEDR/97-02, National Center for Environmental Decision-Making Research, Oak Ridge National Laboratory, University of Tennessee, Knoxville.

Swartjes, F., Cornelis, C., Grundfelt, B. and Satijn, B.: 2003, 'Review of the NICOLE/ISG Risk Assessment Comparison Study', in G.J. Annokkée, F. Arendt and O. Uhlmann (eds.), Proceedings of ConSoil 2003, Gent, B, 12-16 May 2003.

Thayer, W. C., Griffith, D. A., Goodrum, P. E., Diamond, G. L. and Hassett, J. M.: 2003, 'Application of geostatistics to risk assessment', Risk Analysis 23, 945-960.

Twidwell, S. R.: 2000, 'Bioaccumulation of Mercury in Selected East Texas Water Bodies', AS-180, Texas Natural Resource Conservation Commission, Austin.

UNI: 2002, 'Waste - Liquid, Granular, Pasty Wastes and Sludges - Manual Sampling and Preparation and Analysis of Eluates', Ente Nazionale Italiano di Unificazione, Milano.

UNICHIM: 1989, 'Ambienti di Lavoro - Determinazione delle Polveri Atmosferiche - Metodo Gravimetrico', Manual n. 124, Associazione per l'Unificazione nel Settore dell'Industria Chimica, Milano. 
U.S. ACE: 1999, 'A Modular Three-Dimensional Multispecies Transport Model for Simulation of Advection, Dispersion and Chemical Reactions of Contaminants in Groundwater Systems - Documentation and User's Guide', Release DoD_3.50.A, U.S. Army Corps of Engineers, Washington DC.

U.S. EPA: 1989, 'Risk Assessment Guidance for Superfund - Volume I: Human Health Evaluation Manual (Part A)', U.S. Environmental Protection Agency, Office of Emergency and Remedial Response, Washington DC.

U.S. EPA: 1991, 'Screening Methods for the Development of Air Toxics Emission Factors', EPA450/4-91-021, U.S. Environmental Protection Agency, Office of Air Quality Planning and Standards, Emissions Measurement Center, Research Triangle Park, NC.

U.S. EPA: 1994, 'Test Methods for Evaluating Solid Waste', EPA - SW 846, U.S. Environmental Protection Agency, Office of Solid Waste and Emergency Response, Washington DC.

U.S. EPA: 1996, 'Soil Screening Guidance: Technical Background Document', EPA/540/R-95/128, U.S. Environmental Protection Agency, Office of Solid Waste and Emergency Response, Washington DC.

U.S. EPA: 1997, 'Mercury Study Report to Congress. Volume III: Fate and transport of mercury in the environment', EPA-452/R-97-005, U. S. Environmental Protection Agency, Office of Air Quality Planning \& Standards and Office of Research and Development.

U.S. EPA: 1998a, 'Human Health Risk Assessment Protocol for Hazardous Combustion Facilities - Volume 2', EPA-530-D-98-001B, U.S. Environmental Protection Agency, Solid Waste and Emergency Response, Washington DC.

U.S. EPA: 1998b, 'Test Methods for Evaluating Solid Waste', EPA - SW 846, U.S. Environmental Protection Agency, Office of Solid Waste and Emergency Response, Washington DC.

U.S. EPA: 2002a, 'Supplemental Guidance for developing Soil Screening Levels for Superfund Sites', OSWER 9355.4-24, U.S. Environmental Protection Agency, Office of Solid Waste and Emergency Response, Washington DC.

U.S. EPA: 2002b, 'Frontera Creek - Puerto Rico', ID\# PRD980640965, U.S. Environmental Protection Agency, Region 2, Washington DC.

U.S. EPA: 2004a, 'An examination of EPA risk assessment principles and practices', EPA/100/B04/001, U.S. Environmental Protection Agency, Office of Science Advisor, Washington DC.

U.S. EPA: 2004b, 'Region 9 PRG Table', October 2004, U.S. Environmental Protection Agency, Region 9, San Francisco.

U.S. EPA: 2005a, 'Region III RBC Table 4/7/2005', U.S. Environmental Protection Agency, Region 3, Philadelphia.

U.S. EPA: 2005b, 'Region 6 Human Health Medium-Specific Screening Levels 2004-2005', U.S. Environmental Protection Agency, Region 6, Dallas.

U.S. EPA: 2005c, 'Grand Street Mercury - New Jersey', ID\# NJ0001327733, U.S. Environmental Protection Agency, Region 2, Washington DC.

U.S. DHHS: 1999, 'Toxicological Profile for Mercury', U.S. Department of Health and Human Services, Agency for Toxic Substances and Disease Registry, Atlanta.

Waterloo Hydrogeologic: 2001, 'RISC Workbench User's Manual - Human Health Risk Assessment Software for Contaminated Sites', Waterloo.

WHO: 2003, 'Elemental Mercury and Inorganic Mercury Compounds: Human Health Aspects', Concise International Chemical Assessment Document 50, World Health Organization, Geneve. 